\title{
Determination of important enzymes and antimicrobial resistances of gram-positive haloalkaliphilic bacteria isolated from Salda Lake
}

\section{Salda Gölünden izole edilen gram-pozitif haloalkalifik bakterilerin önemli enzimlerinin ve antibiyotik dirençlerinin belirlenmesi}

\section{Pınar Çağlayan}

Division of Plant Diseases and Microbiology, Department of Biology, Faculty of Arts and Sciences, Marmara University, 34722, Istanbul, Turkey

Abstract: As an extreme environment, soda lakes harbor various haloalkaliphilic microorganisms. Salda Lake is one of the natural soda lake (pH $>9$ ) in Turkey. Haloalkaliphiles are unique microorganisms in their ability to live in high alkaline and high saline conditions, and play an important role in biodegradation and bioremediation of hydrocarbons. Hence, the aims of this study were to isolate haloalkaliphilic bacteria from water sample of Salda Lake, to identify these isolates by both conventional and molecular methods, to screen their industrially important enzymes, and to investigate their antimicrobial resistance profiles. Six isolates were identified as Bacillus horneckiae, Bacillus subtilis, Bacillus paramycoides, Bacillus pumilus, Staphylococcus epidermidis, Bacillus haynesii according to 16S rRNA gene sequencing analysis. The industrially important enzymes (amylase, cellulase, pullulanase, lipase, urease, protease, caseinase, oxidase, catalase) were produced by haloalkaliphilic isolates. These enzymes maybe used in alkaline and saline industrial processes. Although Bacillus subtilis was susceptible to all antibiotics, other isolates showed resistance to at least one antibiotic. The resistance against antibiotics were found as ampicillin/sulbactam $83 \%$, amoxycillin/clavulanic acid $83 \%$, ampicillin $67 \%$, mupirocin $67 \%$, chloramphenicol $50 \%$, tetracycline $50 \%$, imipenem $50 \%$, meropenem $50 \%$, cefadroxil $17 \%$. These bacteria may have develope resistance to antibiotics that entering their natural environment in different ways.

Keywords: Microbial enzymes, antibiotic resistance, soda lake, haloalkaliphiles, biodiversity, gram positive bacteria

Öz: Aşırı ortamlar olarak soda gölleri, çeşitli haloalkalifilik mikroorganizmaları barındııı. Salda Gölü, Türkiye'deki doğal soda göllerinden (pH>9) biridir. Haloalkalifiller yüksek alkali ve yüksek tuzlu kosullarda yaşama kabiliyetleri bakımından benzersiz mikroorganizmalardır ve hidrokarbonların biyolojik olarak parçalanması ve biyoremediasyonunda önemli bir rol oynarlar. Bu nedenle, bu çalışmanın amacı haloalkalifilik bakterileri Salda Gölü'nden izole etmek, geleneksel ve moleküler metotlarla tanımlamak, ürettikleri önemli endüstriyel enżimleri ve antibiyotik direnç profillerini araştırmaktır. 16S rRNA gen dizi analizine göre altı adet haloalkalifilik izolat (Bacillus horneckiae, Bacillus subtilis, Bacillus paramycoides, Bacillus pumilus, Staphylococcus epidermidis, Bacillus haynesii) tanımlanmıştır. Endüstriyel öneme sahip amilaz, selülaz, pullulanaz, lipaz, üreaz, proteaz, kazeinaz, oksidaz, katalaz enzimleri haloalkalifilik izolatlar tarafından üretilmiştir. Bu enzimler alkali ve tuzlu endüstriyel işlemlerde kullanılabilir. Bacillus subtilis tüm antibiyotiklere duyarlı olmasına rağmen, diğer izolatlar en az bir antibiyotiğe direnç göstermiştir. Antibiyotiklere direnç; ampisilin/sulbaktam \%83, amoksisilin/klavulanik asit $\% 83 a m p i s i l i n \% 67$, mupirosin $\% 67$, kloramfenikol $\% 50$, tetrasiklin $\% 50$, imipenem $\% 50$, meropenem $\% 50$, sefadroksil $\% 17$ olarak bulunmuştur. Bu bakteriler doğal ortamlarına farklı yollardan giren antibiyotiklere karşı direnç geliştirebilirler.

Anahtar kelimeler: Mikrobiyal enzimler, antibiyotik direnci, soda gölü, haloalkalifiller, biyoçeşitlilik, gram pozitif bakteri

\section{INTRODUCTION}

Extreme environments harbor extremophile microorganisms such as alkaliphiles, halophiles, thermophiles, psychrophiles and acidophiles. These environments have enormous potential for novel enzymes which are salt tolerant, thermostable, active at high $\mathrm{pH}$. Microorganisms that can survive under extreme $\mathrm{pH}$ values are referred as alkaliphiles (Raval et al., 2015). The enzymes of alkaliphiles are used in different industries for various applications (Table 1).

The most widely studied enzymatic group is alkaline proteases (Chand and Mishra, 2003). The researchers reported that Bacillus licheniformis, $B$. subtilis, $B$. amyloliquefaciens and $B$. majovensis produce alkaline protease enzymes (Gupta et al., 2002). Alkaliphilic bacterial species were reported by other researchers. Alkaliphilic
Bacillus cohnii, B. pseudofirmus, and B. clarkii were isolated from bauxite residue in the southern region of Minas Gerais (Brazil) (Nogueira et al., 2017). Haloalkaliphilic bacterial strains belonging to the genera Bacillus, Staphylococcus, Halobacillus, Virgibacillus, Oceanobacillus were isolated from saline desert of Little Rann of Kutch in India (Bhatt et al., 2018). These isolates were able to produce protease, cellulase, carboxymethyl cellulase (CMCase) and amylase enzymes at high salt concentration and high $\mathrm{pH}$ (Bhatt et al., 2018). The researchers also reported that these isolates showed resistance against ampicillin, amikacin, augmentin, cefaclor, colistin, cefoperazone, cefuroxime, cefotaxime, cefixime, erythromycin, azithromycin, co-norfloxacin, trimoxazole, amoxycillin, cefadroxil, cefpodoxime, penicillin and gentamycin (Bhatt et al., 2018). 
Table 1. Microbial enzymes and their industrial applications

\begin{tabular}{|c|c|c|c|}
\hline $\begin{array}{l}\text { Microbial } \\
\text { enzyme }\end{array}$ & Industries using enzymes & The use of enzymes & References \\
\hline \multirow[t]{4}{*}{ Cellulase } & Textile & Softening and shining of clothes & Aygan and Arikan, 2008 \\
\hline & Detergent & Polishing fabrics & Wang et al., 2009 \\
\hline & Agriculture & Production of biofuel from cellulosic material & \\
\hline & & Conversion of agricultural biomass into useful products & \\
\hline \multirow[t]{11}{*}{ Protease } & Detergent & Laundry additives & Chand and Mishra, 2003 \\
\hline & Food & Formulations of detergents & Mitra and Chakrabartty, 2005 \\
\hline & Animal feed & Peptide sythesis & \\
\hline & Baking & Fish sauce preparation & \\
\hline & Biomedical & Dehairing goak skin & \\
\hline & Brewing & & \\
\hline & Cheese & & \\
\hline & Chemistry & & \\
\hline & Tanning & & \\
\hline & Leather & & \\
\hline & Pharmaceutical & & \\
\hline \multirow[t]{5}{*}{ Lipase } & Detergent & Detergent additives & Jaeger and Holliger, 2010 \\
\hline & Food & Enantioselective biocatalyst for the Production of fine chemicals & Babu et al., 2008 \\
\hline & Paper & Esterification & \\
\hline & & Trans-esterification & \\
\hline & & Amynolysis & \\
\hline \multirow[t]{5}{*}{ Xylanase } & Food & Production of coffee, feed and flour & Ratnakar, 2013 \\
\hline & Paper & Removal of lignin from pulp & Khandeparker and Numan, 2008 \\
\hline & Pulp & Increasing loaf volume & \\
\hline & Baking & Production of biofuel & \\
\hline & & Starch production from lignocellulose & \\
\hline Pullulanase & Food & Biocatalysis in organic solvents and super critic fluids & Delgado-García et al., 2015 \\
\hline \multirow[t]{7}{*}{ Amylase } & Textile & Starch saccharification & Ratnakar, 2013 \\
\hline & Food & Strach hydrolysis & Ammar et al., 2002 \\
\hline & Brewing & Saccharification of marine microalgae & Kikani et al., 2010 \\
\hline & Distilling & Removal of starch from clothes & \\
\hline & Detergent & Desizing process & \\
\hline & & Production of syrups & \\
\hline & & Reduction of turbidity of fruit juice & \\
\hline DNase & Food & Acid 5'-guanilic and acid 5'-inosinic as flavor agents & Delgado-García et al., 2015 \\
\hline Urease & Beverage & Removal of urea from wine & Liu et al., 2012 \\
\hline Caseinase & Food & Degrading casein in milk & Johnson and Case, 2010 \\
\hline
\end{tabular}


Salda Lake, which is an extremely alkaline, slightly saline and closed system, is located in the lakes district of Turkey (Balci et al., 2018). Salda Lake is close to Yesilova, located in $44 \mathrm{~km}^{2}$ area and nearly $200 \mathrm{~m}$ deep. In Salda Lake region, agriculture, animal husbandry, livestock, tourism and fishing activities are carried out. The pollutants caused by these activities are mixed into the water of the Salda Lake. The contamination of lake water with antibiotic resistant bacteria may be resulted from the livestock-related or agricultural activities. The researchers reported that the water of the Salda Lake may be used as drinking water in the future (Varol et al., 2021). It should be known which microbial populations live in Salda Lake so that the lake water can be decontaminated with the correct chemicals or methods. Therefore, it is important to isolate and identify haloalkaliphilic bacteria found in Salda Lake water resistant to antibiotics used in human and veterinary medicine.

There are a few reports on the microbial populations found in Salke Lake. Lyngbya majuscula, Gloeocapsa aeruginosa, Synechococcus sp., Microcystis aeruginosa, Chroococcus turgidus and Oscillatoria limnosa were found in Salda Lake by the researchers (Braithwaite and Zedef, 1996; Kazanci et al., 2004; Shirokova et al., 2013). In another study, new generation sequence analysis showed that $97.3 \%$ of the lake belongs to Bacteria domain (Gammaprotobacteria $39.6 \%$ Alphaprotobacteria $25.6 \%$, Bacilli $23.7 \%$, Cyanobacteria 5.3\%, Betaproteobacteria 2\%, Actinobacteria 1.7\%) (Balci et al., 2018).

Antibiotics are used in food animals to treat, control and prevent diseases (Mirzaagha et al., 2011). Although antibiotics are commonly used in animal husbandry to promote growth, in human and veterinary medicine to treat infections caused by bacteria, antibiotic-resistant bacteria increased worldwide because of the misuse and overuse of antibiotics. While the researchers focused on the antibiotic resistance in human, agriculture and animal, much less information is available about antibiotic-resistant bacteria in natural environments. The natural environments contain various reservoir of antimicrobial resistance genes and genetic elements (Berkner et al., 2014). These genes constitute the resistome of environment which are an important part of resistome of human pathogens (Gillings, 2013).

Carbapenems (imipenem, meropenem); cephalosporins 1 st generation (cefadroxil); penicillins- $\beta$-lactam/ $\beta$-lactamase inhibitor combinations (amoxicillin-clavulanic acid, ampicillin, ampicillin/sulbactam); amphenicols (chloramphenicol); tetracyclines (tetracycline) are among the antibiotics which are used in both human and veterinary medicine (WHO, 2017). Hence, chloramphenicol, cefadroxil, ampicillin, tetracycline, mupirocin, imipenem, meropenem, ampicillin/sulbactam and amoxycillin/clavulanic acid were selected as test antibiotics.
According to the literature review, there are no studies in which haloalkaliphilic bacteria were isolated from Salda Lake and identified, and their enzymatic functions and antibiotic susceptibilities were determined. In this respect, this study provided original results. Hence, this study focused on the haloalkaliphilic bacterial diversity of Salda Lake, their enzymatic fuctions in alkaline ecosystem and their antibiotic resistance profiles. Therefore, haloalkaliphilic bacterial species were isolated from water sample collected from Salda Lake; these bacterial isolates were identified at the species level using conventional and molecular methods; their industrially important enzymes were determined; and antibiotic resistance profiles of haloalkaliphilic wild-type bacteria were investigated in the present study.

\section{MATERIALS AND METHODS}

\section{Isolation of haloalkaliphilic bacteria}

Haloalkaliphilic medium containing $5 \mathrm{~g}$ glucose, $4 \mathrm{~g}$ $\mathrm{Na}_{2} \mathrm{~B}_{4} \mathrm{O}_{7} .10 \times \mathrm{H}_{2} \mathrm{O}, 3 \mathrm{~g} \mathrm{NaNO}_{3}, 1 \mathrm{~g} \mathrm{NH}_{4} \mathrm{Cl}, 0.5 \mathrm{~g} \mathrm{KH}_{2} \mathrm{PO}_{4}, 1 \mathrm{~g}$ yeast extract, $0.5 \mathrm{~g}$ casamino acids, $100 \mathrm{~g} \mathrm{NaCl}, 1000 \mathrm{ml}$ distilled water was used for isolation from water sample of Salda Lake (Burdur/Turkey). The final $\mathrm{pH}$ was adjusted to 9. After overnight incubation at $35^{\circ} \mathrm{C}$, different bacterial colonies were selected and restreaked several times to obtain pure cultures, then subjected to phenotypic and genotypic analysis (Gonzales et al., 1978; Rodríguez-Montalvo et al., 1998; Harley and Prescott, 2002).

\section{Amplification and sequencing of 16S rRNA genes}

Chromosomal DNA were extracted and PCR products were purified as described by the manufacturer's instructions (QIAamp DNA Mini Kit, QIAquick PCR Purification Kit, Qiagen). The $16 \mathrm{~S}$ rRNA genes were amplified using specific universal 1492R (5'TACGGYTACCTTGTTACGACTT3') and 27F (5'AGAGTTTGATCMTGGCTCAG 3') primers (Sambrook and Russell, 2001). The $16 \mathrm{~S}$ ribosomal RNA gene sequences were determined by IONTEK Laboratory (Istanbul/Turkey). 16S rRNA gene similarities were further determined between isolates and closely related species by using ChromasPro and EzTaxon-e tool (Kim et al., 2012).

\section{Characterization of the haloalkaliphilic isolates}

Exponentially growing broth cultures of six isolates were examined for cell morphology on prepared wet mounts using light microscopy. Colony pigmentation was observed by growing colonies on haloalkaliphilic agar medium. Gram staining, catalase and oxidase activities were carried out according to the standard procedures (Arahal et al., 1996; Johnson and Case, 2010; Sánchez-Porro et al., 2011). Salt requirement and salt tolerance of the isolates were investigated on plates containing haloalkaliphilic agar medium in which the $\mathrm{NaCl}$ concentration was varied $(0 \%, 1 \%, 1.5 \%$, $2 \%, 5 \%, 7.5 \%, 10 \%, 12.5 \%, 15 \%, 17.5 \%, 20 \% \mathrm{NaCl})$. The pH tolerance of the isolates was tested on haloalkaliphilic agar 
medium adjusted to $\mathrm{pH}$ values of 5-13. To determine optimum growth temperature of the isolates, the plates inoculated with each isolate were incubated at different temperatures $\left(4^{\circ} \mathrm{C}\right.$ $\left.60^{\circ} \mathrm{C}\right)$.

\section{Enzymatic activities of the haloalkaliphilic isolates}

Amylase activity was detected using haloalkaliphilic agar medium supplemented with $0.5 \%(\mathrm{w} / \mathrm{v})$ soluble starch. After incubation, the plate was flooded with $0.3 \% \quad \mathrm{I}_{2}-0.6 \% \mathrm{KI}$ solution. Clear halos around the colonies indicated starch hydrolysis. The DNase test agar was used to determine DNase activity. After incubation, the plate was flooded with $1 \mathrm{~N} \mathrm{HCl}$. Clear zones around the colonies showed hydrolysis of DNA (Sánchez-Porro et al., 2003). The cellulose medium agar plate containing $0.2 \%$ (w/v) carboxymethyl cellulose was used to detect production of cellulase. After incubation, $0.1 \%$ congo red test reagent was flooded on the colonies and left for $30 \mathrm{~min}$. Then, the colonies were washed with $1 \mathrm{M} \mathrm{NaCl}$ solution. Clear zones around the colonies showed cellulase activity (Birbir et al., 2007). Hydrolysis of casein was tested with the Plate Count Agar medium containing 2\% skim milk. After incubation, clear zones around the colonies were interpreted as caseinase production (Sánchez-Porro et al., 2011). Lipase activity was screened on Tween 80 agar medium containing $1 \%(\mathrm{w} / \mathrm{v})$ Tween 80 . After incubation, opaque zones around the colonies were accepted as evidence of lipase activity (Caglayan et al., 2018). Protease activity was screened on gelatin agar medium containing $2 \%$ gelatin (w/v). After incubation, the plate was flooded with Frazier solution. Clear zones around the colonies were interpreted as positive protease activities (Sánchez-Porro et al., 2003). Urease activity was detected on Christensen Urea Agar. After growth was obtained, the tube was examined for pink or red color changes (Johnson and Case, 2010). To detect pullulolytic and xylanolytic activities of the isolates, plates containing the chromogenic substrates such as azurine-cross-linked (AZCL)-pullulan and AZCL-xylan were respectively used. Clear zones around the colonies were accepted as positive pullulolytic and xylanolytic activities (Sánchez-Porro et al., 2003; Caglayan et al., 2017). The pH of all media was adjusted to 9 .

\section{Nucleotide accesion number}

16S rRNA sequence data of the haloalkaliphilic water isolates S10, S4A, S6, S2, S1, S4, reported in this article have been deposited in NCBI and GenBank nucleotide sequence database under the respective accession numbers: MH752438, MH748635, MH748638, MH748643, MH748647, $\mathrm{MH} 748673$.

\section{Antimicrobial susceptibility tests}

The haloalkaliphilic isolates were grown in Mueller Hinton Broth containing $1 \%(\mathrm{w} / \mathrm{v}) \mathrm{NaCl}$. After the overnight incubation at $35^{\circ} \mathrm{C}$, the optical densities of the bacterial suspensions were adjusted to McFarland Standard No $0.5\left(1 \times 10^{8} \mathrm{CFU} / \mathrm{mL}\right)$ with sterile saline solution $(1 \% \mathrm{NaCl})$. The Kirby-Bauer disc diffusion method was used to determine the resistance of isolates to antibiotics such as chloramphenicol $(30 \mu \mathrm{g})$, cefadroxil $(30 \mu \mathrm{g})$, ampicillin $(10 \mu \mathrm{g})$, tetracycline $(30 \mu \mathrm{g})$, mupirocin $(20 \mu \mathrm{g})$, imipenem $(10 \mu \mathrm{g})$, meropenem $(10 \mu \mathrm{g})$, ampicillin/sulbactam $(10 / 10 \mu \mathrm{g} ; 20 \mu \mathrm{g})$ and amoxycillin/clavulanic acid $(20 / 10 \mu \mathrm{g} ; 30 \mu \mathrm{g})$. The surface of the Mueller Hinton Agar plates were inoculated with bacterial suspension of each test isolate and antibiotic discs (Oxoid, UK) were placed on the surface. After 24 hours incubation of plates at $35^{\circ} \mathrm{C}$, the inhibition zone diameters were mesured and evaluated according to zone diameter distributions of wildtype microorganisms and ECOFF information explained by European Committee on Antimicrobial Susceptibility Testing as resistant and susceptible (EUCAST, 2014).

\section{RESULTS}

\section{Phylogenetic analysis of haloalkaliphilic bacteria}

The $16 \mathrm{~S}$ ribosomal RNA gene sequences and the $16 \mathrm{~S}$ rRNA the pairwise sequence similarities of the haloalkaliphilic isolates were respectively found as 1155-1299 bp and 98.1$100 \%$. Two different genera, Staphylococcus (1 isolate) and Bacillus (5 isolates), were determined in Firmicutes (Table 2). The colonies of haloalkaliphilic bacterial isolates on haloalkaliphilic medium agar plates were yellow, cream and white. All of the isolates were Gram-positive. Cell morphologies of the isolates were coccus and rod-shaped. All isolates grew at $0-7.5 \%$ salt concentrations and $\mathrm{pH}$ range 7 12. Four and two isolates respectively showed optimum growth at $1.5 \%$ and $1 \%$ salt concentrations. All isolates showed optimum growth at $\mathrm{pH} 9$. While five isolates grew at $10-55^{\circ} \mathrm{C}$, only one isolate grew at $10-60^{\circ} \mathrm{C}$. Four isolates, one isolate and one isolate were respectively exhibited optimum growth at $35^{\circ} \mathrm{C}, 37^{\circ} \mathrm{C}$ and $35-37^{\circ} \mathrm{C}$ (Table 2).

Catalase $(100 \%)$, oxidase $(67 \%)$, protease $(50 \%)$, cellulase $(50 \%)$, lipase $(33 \%)$, caseinase $(33 \%)$, urease $(17 \%)$, amylase $(17 \%)$, and pullulanase $(17 \%)$ were produced by the isolates (Table 2). Xylanase and deoxyribonuclease were not produced. The isolates showed combined enzymatic activities. Bacillus haynesii (catalase, protease) and Bacillus horneckiae (catalase, cellulase) produced two enzymes. Bacillus subtilis produced oxidase, catalase and cellulase. Bacillus paramycoides, Bacillus pumilus, and Staphylococcus epidermidis respectively produced seven (oxidase, catalase, amylase, cellulase, urease, protease, caseinase), five (oxidase, catalase, lipase, protease, caseinase) and four (oxidase, catalase, pullulanase, lipase) enzymes. Among the isolates Bacillus paramycoides produced all enzymes except pullulanase, xylanase, lipase and deoxyribonuclease. It is known that the haloalkaliphilic bacteria and their enzymes are active and stable under harsh conditions. Therefore, the test isolates may have potential for novel enzymes due to their ability to be stable under saline conditions and high $\mathrm{pH}$. The enzymes of haloalkaliphiles such as oxidase, catalase amylase, cellulase, pullulanase, lipase, urease, protease, 
caseinase may be used in several industrial applications. In order to characterize the properties of these enzymes and determine their biochemical reactions, more detailed studies are needed to be performed.

Table 2. Characteristics of haloalkaliphilic bacteria isolated from water sample in Salda Lake

\begin{tabular}{|c|c|c|c|c|c|c|}
\hline \multirow[b]{2}{*}{ Characteristics } & \multirow[t]{2}{*}{$\begin{array}{l}\text { Staphylococcus } \\
\text { epidermidis }\end{array}$} & \multirow[t]{2}{*}{ Bacillus subtilis } & \multirow[t]{2}{*}{ Bacillus pumilus } & \multirow[t]{2}{*}{$\begin{array}{c}\text { Bacillus } \\
\text { paramycoides }\end{array}$} & \multirow[t]{2}{*}{ Bacillus haynesii } & \multirow[t]{2}{*}{$\begin{array}{c}\text { Bacillus } \\
\text { horneckiae }\end{array}$} \\
\hline & & & & & & \\
\hline Isolate code & S10 & S4A & S6 & S2 & S1 & S4 \\
\hline Gram staining & + & + & + & + & + & + \\
\hline Colony pigmentation & yellow & cream & cream & white & cream & yellow \\
\hline Cell morphology & coccus & rod-shaped & rod shaped & rod-shaped & rod-shaped & rod-shaped \\
\hline $\mathrm{NaCl}$ range $(\%)$ & $0-10$ & $0-10$ & $0-7.5$ & $0-10$ & $0-10$ & $0-12.5$ \\
\hline Optimum $\mathrm{NaCl}(\%)$ & 1 & 1.5 & 1.5 & 1 & 1.5 & 1.5 \\
\hline Temperature range $\left({ }^{\circ} \mathrm{C}\right)$ & $10-55$ & $10-55$ & $10-55$ & $10-55$ & $10-60$ & $10-55$ \\
\hline Optimum temperature $\left({ }^{\circ} \mathrm{C}\right)$ & 37 & 35 & 35 & $35-37$ & 35 & 35 \\
\hline $\mathrm{pH}$ range & $7-12$ & $7-12$ & $7-12$ & $7-12$ & $7-12$ & $7-12$ \\
\hline Optimum pH & 9 & 9 & 9 & 9 & 9 & 9 \\
\hline Oxidase & + & + & + & + & - & - \\
\hline Catalase & + & + & + & + & + & + \\
\hline Amylase & - & - & - & + & - & - \\
\hline Cellulase & - & + & - & + & - & + \\
\hline Pullulanase & + & - & - & - & - & - \\
\hline Xylanase & - & - & - & - & - & - \\
\hline Lipase & + & - & + & - & - & - \\
\hline Urease & - & - & - & + & - & - \\
\hline Protease & - & - & + & + & + & - \\
\hline Caseinase & - & - & + & + & - & - \\
\hline Deoxyribonuclease & - & - & - & - & - & - \\
\hline
\end{tabular}

\section{Antibiotic resistance profiles of haloalkaliphilic bacteria}

The zone diameter breakpoints were determined for chloramphenicol (30 $\mathrm{\mu g} \geq 18 \mathrm{~mm}$ susceptible), cefadroxil (30 $\mu \mathrm{g} \geq 12 \mathrm{~mm}$ susceptible), ampicillin $(10 \mu \mathrm{g} \geq 12 \mathrm{~mm}$ susceptible), tetracycline (30 $\mathrm{mg} \geq 22 \mathrm{~mm}$ susceptible), mupirocin (20 $\mathrm{mg} \geq 30 \mathrm{~mm}$ susceptible), imipenem (10 $\mu \mathrm{g}$ $\geq 24 \mathrm{~mm}$ susceptible), meropenem $(10 \mu \mathrm{g} \quad \geq 25 \mathrm{~mm}$ susceptible), ampicillin/sulbactam ( $20 \mu \mathrm{g} \geq 17 \mathrm{~mm}$ susceptible) and amoxycillin/clavulanic acid ( $30 \mu \mathrm{g} \geq 19 \mathrm{~mm}$ susceptible) according to zone diameter distributions of wildtype microorganisms and ECOFF information (EUCAST, 2014).

The diameter of inhibition zones around chloramphenicol with the highest inhibition zone observed against Bacillus horneckiae (23 mm), followed by Staphylococcus epidermidis (22 mm), Bacillus subtilis (21 mm); around cefadroxil with the highest inhibition zone observed against Bacillus paramycoides and Bacillus haynesii $(20 \mathrm{~mm})$, followed by Bacillus horneckiae (19 mm), Bacillus pumilus $(18 \mathrm{~mm})$, Bacillus subtilis (17 mm); around ampicillin with the highest inhibition zone observed against Bacillus haynesii (22 mm), followed by Bacillus subtilis ( $21 \mathrm{~mm})$; around tetracycline with the highest inhibition zone observed against Staphylococcus epidermidis and Bacillus horneckiae $(25 \mathrm{~mm})$, followed by
Bacillus subtilis (23 mm); around mupirocin with the highest inhibition zone observed against Bacillus haynesii (34 mm), followed by Bacillus subtilis (32 $\mathrm{mm})$; around imipenem with the highest inhibition zone observed against Bacillus paramycoides $(26 \mathrm{~mm})$, followed by Bacillus subtilis and Bacillus horneckiae $(25 \mathrm{~mm})$; around meropenem with the highest inhibition zone observed against Bacillus pumilus (30 $\mathrm{mm})$, followed by Bacillus subtilis $(28 \mathrm{~mm})$ and Bacillus haynesii $(27 \mathrm{~mm})$. The diameter of inhibition zones around ampicillin/sulbactam and amoxycillin/clavulanic acid against Bacillus subtilis were respectively measured as $18 \mathrm{~mm}$ and $22 \mathrm{~mm}$ (Table 3).

Moreover, Staphylococcus epidermidis, Bacillus pumilus, Bacillus paramycoides, Bacillus haynesii, Bacillus horneckiae showed no zone of inhibition around cefadroxil, ampicillin, mupirocin, imipenem, meropenem, ampicillin/sulbactam, amoxycillin/clavulanic acid; chloramphenicol, ampicillin, tetracycline, mupirocin, imipenem, ampicillin/sulbactam, amoxycillin/clavulanic acid; chloramphenicol, ampicillin, tetracycline, mupirocin, meropenem, ampicillin/sulbactam, amoxycillin/clavulanic acid; chloramphenicol, tetracycline, imipenem, ampicillin/sulbactam, amoxycillin/clavulanic acid; ampicillin, mupirocin, meropenem, ampicillin/sulbactam, amoxycillin/clavulanic acid (Table 3). 
Table 3. Antibiotic resistance profiles of haloalkaliphilic bacteria isolated from water sample in Salda Lake

\begin{tabular}{|c|c|c|c|c|c|c|c|c|}
\hline \multirow[t]{2}{*}{ Antibiotics } & \multirow[t]{2}{*}{$\begin{array}{l}\text { Staphylococcus } \\
\text { epidermidis }\end{array}$} & \multirow[t]{2}{*}{$\begin{array}{l}\text { Bacillus } \\
\text { subtilis }\end{array}$} & \multirow[t]{2}{*}{$\begin{array}{l}\text { Bacillus } \\
\text { pumilus }\end{array}$} & \multirow[t]{2}{*}{$\begin{array}{l}\text { Bacillus } \\
\text { paramycoides }\end{array}$} & \multirow[t]{2}{*}{$\begin{array}{l}\text { Bacillus } \\
\text { haynesii }\end{array}$} & \multirow[t]{2}{*}{$\begin{array}{l}\text { Bacillus } \\
\text { horneckiae }\end{array}$} & \multirow[b]{2}{*}{$\mathrm{R} \%$} & \multirow[b]{2}{*}{$\mathbf{S} \%$} \\
\hline & & & & & & & & \\
\hline Chloramphenicol & $\begin{array}{c}\mathrm{S} \\
(22 \mathrm{~mm})\end{array}$ & $\begin{array}{c}\mathrm{S} \\
(21 \mathrm{~mm})\end{array}$ & $\begin{array}{l}\mathrm{R} \\
(0)\end{array}$ & $\begin{array}{l}R \\
(0)\end{array}$ & $\begin{array}{l}R \\
(0)\end{array}$ & $\begin{array}{c}\mathrm{S} \\
(23 \mathrm{~mm})\end{array}$ & 50 & 50 \\
\hline Cefadroxil & $\begin{array}{l}R \\
(0)\end{array}$ & $\underset{(17 \mathrm{~mm})}{S}$ & $\begin{array}{c}\mathrm{S} \\
(18 \mathrm{~mm})\end{array}$ & $\begin{array}{c}\mathrm{S} \\
(20 \mathrm{~mm})\end{array}$ & $\begin{array}{c}\mathrm{S} \\
(20 \mathrm{~mm})\end{array}$ & $\begin{array}{c}\mathrm{S} \\
(19 \mathrm{~mm})\end{array}$ & 17 & 83 \\
\hline Ampicillin & $\begin{array}{l}R \\
(0)\end{array}$ & $\begin{array}{c}\mathrm{S} \\
(21 \mathrm{~mm})\end{array}$ & $\begin{array}{l}R \\
(0)\end{array}$ & $\begin{array}{l}R \\
(0)\end{array}$ & $\begin{array}{c}\mathrm{S} \\
(22 \mathrm{~mm})\end{array}$ & $\begin{array}{c}R \\
(0)\end{array}$ & 67 & 33 \\
\hline Tetracycline & $\begin{array}{c}\mathrm{S} \\
(25 \mathrm{~mm})\end{array}$ & $\begin{array}{c}\mathrm{S} \\
(23 \mathrm{~mm})\end{array}$ & $\begin{array}{l}R \\
(0)\end{array}$ & $\begin{array}{l}R \\
(0)\end{array}$ & $\begin{array}{l}R \\
(0)\end{array}$ & $\begin{array}{c}\mathrm{S} \\
(25 \mathrm{~mm})\end{array}$ & 50 & 50 \\
\hline Mupirocin & $\begin{array}{l}R \\
(0)\end{array}$ & $\begin{array}{c}\mathrm{S} \\
(32 \mathrm{~mm})\end{array}$ & $\begin{array}{l}R \\
(0)\end{array}$ & $\begin{array}{l}R \\
(0)\end{array}$ & $\begin{array}{c}\mathrm{S} \\
(34 \mathrm{~mm})\end{array}$ & $\begin{array}{l}R \\
(0)\end{array}$ & 67 & 33 \\
\hline Imipenem & $\begin{array}{l}R \\
(0)\end{array}$ & $\begin{array}{c}S \\
(25 \mathrm{~mm})\end{array}$ & $\begin{array}{l}R \\
(0)\end{array}$ & $\begin{array}{c}\mathrm{S} \\
(26 \mathrm{~mm})\end{array}$ & $\begin{array}{l}R \\
(0)\end{array}$ & $\begin{array}{c}\mathrm{S} \\
(25 \mathrm{~mm})\end{array}$ & 50 & 50 \\
\hline Meropenem & $\begin{array}{l}R \\
(0)\end{array}$ & $\begin{array}{c}S \\
(28 \mathrm{~mm})\end{array}$ & $\begin{array}{c}\mathrm{S} \\
(30 \mathrm{~mm})\end{array}$ & $\begin{array}{l}R \\
(0)\end{array}$ & $\begin{array}{c}\mathrm{S} \\
(27 \mathrm{~mm})\end{array}$ & $\begin{array}{l}R \\
(0)\end{array}$ & 50 & 50 \\
\hline Ampicillin/sulbactam & $\begin{array}{l}R \\
(0)\end{array}$ & $\begin{array}{c}\mathrm{S} \\
(18 \mathrm{~mm})\end{array}$ & $\begin{array}{l}R \\
(0)\end{array}$ & $\begin{array}{l}R \\
(0)\end{array}$ & $\begin{array}{l}R \\
(0)\end{array}$ & $\begin{array}{l}R \\
(0)\end{array}$ & 83 & 17 \\
\hline Amoxycillin/clavulanic acid & $\begin{array}{l}R \\
(0)\end{array}$ & $\begin{array}{c}\mathrm{S} \\
(22 \mathrm{~mm})\end{array}$ & $\begin{array}{l}R \\
(0)\end{array}$ & $\begin{array}{l}R \\
(0)\end{array}$ & $\begin{array}{l}\mathrm{R} \\
(0)\end{array}$ & $\begin{array}{l}R \\
(0)\end{array}$ & 83 & 17 \\
\hline Multidrug resistant bacteria & 7 & 0 & 7 & 7 & 5 & 5 & & \\
\hline
\end{tabular}

$\mathrm{R} \%$, Percentage of isolates resistant to antibiotics; $\mathrm{S} \%$, Percentage of isolates susceptible to antibiotics

All isolates showed resistance to at least one antibiotic tested except Bacillus subtilis. This isolate was susceptible to all antibiotics. While more than half of the isolates were resistant to ampicillin/sulbactam (83\%), amoxycillin/clavulanic acid $(83 \%)$, ampicillin $(67 \%)$, mupirocin $(67 \%)$, less than half of the isolates were resistant to cefadroxil $17 \%$. Fifty percent of the isolates exhibited resitance to chloramphenicol, tetracycline, imipenem, and meropenem (Table 3). Multidrug resistant bacteria, which are able to survive and grow in the presence of two or more antibiotics, were detected as Bacillus horneckiae, Bacillus paramycoides, Bacillus pumilus, Staphylococcus epidermidis and Bacillus haynesii (Table 3).

\section{DISCUSSION}

Bacillus species are widely distributed in water, seawater, soil, marine sediments, and salt. In previous studies, the species isolated and tested in the present study, were isolated from different locations. Bacillus horneckiae was isolated from a spacecraft-assembly clean room in the Kennedy Space Center (Vaishampayan et al., 2010). In that study, Bacillus horneckiae showed weak protease and lipase activities (Vaishampayan et al., 2010). However, this isolate was protease and lipase negative in the present study. Bacillus subtilis was isolated from human gastrointestinal tract (ileum biopsies, faecal samples) (Hong et al., 2009) and dairy effluent (Vijayalakshmi and Murali, 2015). Similar to the results obtained from the study performed by Hong et al. (2009), we observed that Bacillus subtilis was amylase negative, and was able to grow at $10-50^{\circ} \mathrm{C}$. Bacillus paramycoides was isolated from sediment of the South China Sea (Liu et al., 2017) and soil samples collected from rhizospheres of crop plants (Osman and Yin, 2018). Bacillus paramycoides was found as amylase and protease positive in the study of Liu et al. (2017) and in the present study. It was reported that this species showed growth at $15-39^{\circ} \mathrm{C}$ (optimum $30^{\circ} \mathrm{C}$ ), $0-5 \% \mathrm{NaCl}$ concentration (optimum $0.5 \%$ $\mathrm{NaCl}$ ), 5-9 pH range (optimum pH 7) (Liu et al., 2017). This species was reported as plant growth-promoting rhizobacteria (Osman and Yin, 2018). Bacillus pumilus was isolated from coastal environment of Cochin in India (Parvathi et al., 2009) and marine ecosystems (Liu et al., 2013). Similar to the results of this study, Bacillus pumilus showed negative deoxyribonuclease activity, and positive lipase and protease activities (Parvathi et al., 2009). Daptomycin-resistant Staphylococcus epidermidis was isolated from bovine udders (Brown et al., 1969) and patients (Eladli et al., 2018). Bacillus haynesii was isolated from desert soil (Dunlap et al., 2017). According to the results of that study, Bacillus haynesii was able to grow at $\mathrm{pH}$ 5.5-10 (optimum $\mathrm{pH} 7$ ), temperatures of $15-60^{\circ} \mathrm{C}$ (optimum $37^{\circ} \mathrm{C}$ ), and at $0-12 \% \mathrm{NaCl}$ concentrations (Dunlap et al., 2017).

This is the first study on the isolation and characterization of haloalkaliphilic bacteria from water sample of Salda Lake, screening their industrial enzymes, and testing antibiotic resistance profiles. The haloalkaliphilic Bacillus horneckiae Bacillus subtilis, Bacillus paramycoides, Bacillus pumilus, Staphylococcus epidermidis, Bacillus haynesii species, isolated from Salda Lake, were first reported in the present study. These isolates were found resistant to different antibiotics in the present study. The agricultural, livestock, tourism and fishing activities are considered, these antibiotic resistant bacteria may have harmful impacts on water 
sources. Furthermore, amylase, cellulase, pullulanase, lipase, urease, protease, caseinase, oxidase, catalase produced by these isolates would be important candidates for various industrial applications due to enzymatic activity and stability in a broader range of $\mathrm{NaCl}$ and $\mathrm{pH}$.

\section{CONCLUSION}

Haloalkaliphilic bacteria display different morphological, physiological, molecular and cultural characteristics, Gram staining reaction, biochemical features, antibiotic susceptibility profiles, enzyme and metabolite production. Alkaline

\section{REFERENCES}

Ammar, Y.B., Matsubara, T., Ito, K., Lizuka, M., Limpaseni, T., Pongsawasdi, P. \& Minamiura, N. (2002). Characterization of a thermostable levansucrase from Bacillus sp. TH4-2 capable of producing high molecular weight levan at high temperature. Journal of Biotechnology, 99, 111-119. DOI: 10.1016/s0168-1656(02)00160-8

Arahal, D.R., Dewhirst, F.E., Paster, B.J., Volcani, B.E. \& Ventosa, A. (1996). Phylogenetic analyses of some extremely halophilic archaea isolated from dead sea water, determined on the basis of their 16S rRNA sequences. Applied and Environmental Microbiology, 62, 3779-3786. DOI: 10.1128/AEM.62.10.3779-3786.1996

Aygan, A. \& Arikan, B. (2008). A new haloalkaliphilic, thermostable endoglucanase from moderately halophilic Bacillus sp. C14 isolated from Van Soda Lake. International Journal of Agriculture and Biology, 10, 369-374.

Babu, J., Pramod, W.R. \& George, T. (2008). Cold active microbial lipases: Some hot issues and recent developments. Biotechnology Advances, 26, 457-470. DOI: 10.1016/j.biotechadv.2008.05.003

Balci, N., Demirel, C. \& Kurt, M.A. (2018). Geomicrobiology of Lake Salda and microbial influences on present-day stromatolite formation, Bulletin of the Earth Sciences Application and Research Centre of Hacettepe University, 39, 1, 19-40.

Berkner, S., Konradi, S. \& Schönfeld, J. (2014). Antibiotic resistance and the environment-there and back again. EMBO Reports, 15, 7, 740-744. DOI: 10.15252/embr.201438978

Bhatt, H.B., Gohel, S.D. \& Singh, S.P. (2018). Phylogeny, novel bacterial lineage and enzymatic potential of haloalkaliphilic bacteria from the saline coastal desert of Little Rann of Kutch, Gujarat, India. 3 Biotech, 8, 53, 1-12. DOI: 10.1007/s13205-017-1075-0

Birbir, M., Calli, B., Mertoglu, B., Elevi Bardavid, R., Oren, A., Ogmen, M.N. \& Ogan, A. (2007). Extremely halophilic archaea from Tuz Lake, Turkey, and the adjacent Kaldirim and Kayacik salterns. World Journal of Microbiology and Biotechnology, 23, 309-316. DOI: 10.1007/s11274-006-9223-4

Braithwaite, C.J.R. \& Zedef, V. (1996). Hydromagnesite stromatolites and sediments in an alkaline lake, Salda Gölü, Turkey. Journal of Sedimentary Research, 66, 991-1002.

DOI: 10.1306/D426845F-2B26-11D7-8648000102C1865D

Brown, R.W., Sandvik, O., Scherer, R.K. \& Rose, D.L. (1969). Differentiation of strains of Staphylococcus epidermidis isolated from bovine udders. Journal of General Microbiology, 47, 273-287.

DOI: 10.1306/D426845F-2B26-11D7-8648000102C1865D

Caglayan, P., Birbir, M., Sánchez-Porro, C. \& Ventosa, A. (2017). Screening of Industrially Important Enzymes Produced by Moderately Halophilic Bacteria Isolated from Salted Sheep Skins of Diverse Origin. Journal of The American Leather Chemists Association, 112(6), 207-216.

Caglayan, P., Birbir, M., Sánchez-Porro, C., Ventosa, A. \& Birbir, Y. (2018). Investigation of moderately halophilic bacteria causing deterioration of the salted sheep and goat skins and their extermination via electric current applications. Journal of the American Leather Chemists Association, 113, 41-52. environments harbor diverse haloalkaliphilic bacteria producing stable enzymes. Due to the stability and activity of alkaline enzymes in harsh conditions, they have potential to be used in biotechnological applications. Future performed investigations with their metabolites are very important considering their ability to survive under high $\mathrm{pH}$. The presence of multidrug resistant bacteria in Salda Lake was detected. Antibiotic resistant Bacillus and Staphylococcus species present in the Salda Lake may be transmitted by human, animal, air, soil, or wastewater. These genes are present in natural environments worldwide.

Chand, S. \& Mishra, P. (2003). Research and application of microbial enzymes, India's contribution. Advances in Biochemical Engineering/Biotechnology, 85, 95-124. DOI: 10.1007/3-540-36466-8_4

Delgado-García, M., Nicolaus, B., Poli, A., Aguilar, C.N. \& RodríguezHerrera, R. (2015). Isolation and screening of halophilic bacteria for production of hydrolytic enzymes. In: Maheshwari D, Saraf M (eds) Halophiles, Sustainable Development and Biodiversity, Springer, 396. DOI: 10.1007/978-3-319-14595-2_14

Dunlap, C.A., Schisler, D.A., Perry, E.B., Connor, N., Cohan, F.M. \& Rooney, A.P. (2017). Bacillus swezeyi sp. nov. and Bacillus haynesii sp. nov., isolated from desert soil. International Journal of Systematic and Evolutionary Microbiology, 67, 2720-2725. DOI:10.1099/ijsem.0.002007

Eladli, M.G., Alharbi, N.S., Khaled, J.M., Kadaikunnan, S., Alobaidi, A.S. \& Alyahya, S.A. (2019). Antibiotic-resistant Staphylococcus epidermidis isolated from patients and healthy students comparing with antibioticresistant bacteria isolated from pasteurized milk. Saudi Journal of Biological Sciences, 26, 6, 1285-1290. DOI: 10.1016/j.sjbs.2018.05.008

EUCAST (The European Committee on Antimicrobial Susceptibility Testing), (2014) Breakpoint Tables for Interpretation of MICs and Zone Diameters, Version4.0,https://mic.eucast.org/Eucast2/SearchController/search.jsp?a ction=init, Last accessed date: 10 February 2021.

Gillings, M.R. (2013). Evolutionary consequences of antibiotic use for the resistome, mobilome and microbial pangenome. Frontiers in Microbiology, 4, 4, 1-10. DOI: 10.3389/fmicb.2013.00004

Gonzales, C., Gutierrez, C. \& Ramirez, C. (1978). Halobacterium vallismortis sp. nov. an amylolytic and carbohydrate-metabolizing extremely halophilic bacterium. Canadian Journal of Microbiology, 24, 710-715. DOI: 10.1139/m78-119

Gupta, R., Beg, Q. \& Lorenz, P. (2002). Bacterial alkaline proteases: molecular approaches and industrial applications. Applied Microbiology and Biotechnology, 59, 15-32. DOI: 10.1007/s00253-002-0975-y

Harley, J.P. \& Prescott, L.M. (2002). Laboratory exercises in microbiology. The McGraw-Hill Companies, New York.

Hong, H.A., Khaneja, R., Tam, N.M.K., Cazzato, A., Tan, S., Urdaci, M., Brisson, A., Gasbarrini, A., Barnes, I. \& Cutting, S.M. (2009). Bacillus subtilis isolated from the human gastrointestinal tract. Research in Microbiology, 160, 134-143. DOI: 10.1016/j.resmic.2008.11.002

Jaeger, K.E. \& Holliger, P. (2010). Chemical biotechnology a marriage of convenience and necessity. Current Opinion in Biotechnology, 21, 711712. DOI: 10.1016/j.copbio.2010.09.017

Johnson, T.R. \& Case, C.L. (2010). Laboratory Experiments in Microbiology. Pearson Education, San Francisco

Kazanci, N., Girgin, S. \& Dügel, M. (2004). On the limnology of Salda Lake, a large and deep soda lake in southwestern Turkey: future management proposals, aquatic conservation. Aquatic Conservation: Marine and Freshwater Ecosystems, 14, 151-162. DOI: 10.1002/aqc.609 
Khandeparker, R. \& Numan, M.T. (2008). Bifunctional xylanases and their potential use in biotechnology. Industrial Microbiology and Biotechnology, 35, 7, 63-644. DOI: 10.1007/s10295-008-0342-9

Kikani, B.A., Shukla, R.J. \& Singh, S.P. (2010). Biocatalytic potential of thermophilic bacteria and actinomycetes. In A. Mendez-Vilas (Ed) Current Research, Technology and Education Topics in Applied Microbiology and Microbial Biotechnology, Formatex Research Center, Badajoz, 1000-1007.

Kim, O.S., Cho, Y.J., Lee, K., Yoon, S.H., Kim, M., Na, H., Park, S.C., Jeon, Y.S., Lee, J.H., Yi, H., Won, S. \& Chun, J. (2012). Introducing EzTaxon: a prokaryotic $16 \mathrm{~S}$ rRNA gene sequence database with phylotypes that represent uncultured species. International Journal of Systematic and Evolutionary Microbiology, 62, 716-721. DOI: 10.1099/ijs.0.038075-0

Liu, J., Xu, Y., Nie, Y. \& Zhao, G.A. (2012). Optimization production of acid urease by Enterobacter sp. in an approach to reduce urea in Chinese rice wine. Bioprocess and Biosystems Engineering, 35, 651-657. DOI: $10.1007 / \mathrm{s} 00449-011-0643-7$

Liu, Y., Lai, Q. \& Dong, C. (2013). Phylogenetic diversity of the Bacillus pumilus group and the marine ecotype revealed by multilocus sequence. Plos One, 8, 11, 1-11. DOI: 10.1371/journal.pone.0080097

Liu, Y., Du, J., Lai, Q., Zeng, R., Ye, D., Xu, J. \& Shao, Z. (2017). Proposal of nine novel species of the Bacillus cereus group. International Journal of Systematic and Evolutionary Microbiology, 67, 2499-2508. DOI: 10.1099/ijsem.0.001821

Mirzaagha, P., Louie, M., Sharma, R., Yanke, L.J., Topp, E. \& McAllister, T.A. (2011). Distribution and characterization of ampicillin and tetracyclineresistant Escherichia coli from feedlot cattle fed subtherapeutic antimicrobials. BMC Microbiology, 11, 1-15. DOI: 10.1186/1471-2180-11-78

Mitra, P. \& Chakrabartty, P.K. (2005). An extracellular protease with depilation activity from Streptomyces nogalator. Journal of Scientific and Industrial Research, 64, 12, 978-983.

Nogueira, E.W., Hayash, E.A., Alves, E., Lima, C.A.A., Adorno, M.T. \& Brucha, G. (2017). Characterization of alkaliphilic bacteria isolated from Bauxite Residue in the Southern Region of Minas Gerais, Brazil. Brazilian Archives of Biology and Technology, 60, 1-7. DOI: 10.1590/1678-4324-2017160215

Osman, N.I. \& Yin, S. (2018). Isolation and characterization of pea plant (Pisum sativum L.) growth-promoting Rhizobacteria. African Journal of Microbiology Research, 12, 34, 820-828. DOI: 10.5897/AJMR2018.8859

Parvathi, A., Krishna, K., Jose, J., Joseph, N. \& Nair, S. (2009). Biochemical and molecular characterization of Bacillus pumilus isolated from coastal environment in Cochin, India. Brazilian Journal of Microbiology, 40, 269275. DOI: $10.1590 / S 1517-838220090002000012$

Raval, H., Purohit, M.K. \& Singh, S.P. (2015). Extracellular proteases from Halophilic and Haloalkaliphilic bacteria: Occurrence and biochemical properties. In D. Maheshwari, M. Saraf (eds), Halophiles, Sustainable
Development and Biodiversity, Springer, 421-441.

DOI: 10.1007/978-3-319-14595-2_16

Ratnakar, D. (2013). Use of halophile physiology and adaptations in various industrial applications. Research Journal of Biotechnology, 8, 2, 1-3.

Rodríguez-Montalvo, R., Vreeland, R.H., Oren, A., Kessel, M. \& Lopez, G. (1998). Halogeometricum borinquiense gen. nov. sp. nov. a novel halophilic archeon from Puerto Rico. International Journal of Systematic Bacteriology, 48, 1305-1312. DOI: 10.1099/00207713-48-4-1305

Sambrook, J. \& Russell, D.W. (2001). A Laboratory Manual, Cold Spring Harbor, New York, 20-30.

Sánchez-Porro, C., Martín, S., Mellado, E. \& Ventosa, A. (2003). Diversity of moderately halophilic bacteria producing extracellular hydrolytic enzymes. Journal of Applied Microbiology, 94, 295-300. DOI: 10.1046/j.1365-2672.2003.01834.x

Sánchez-Porro, C., Yilmaz, P., De la Haba, R.R., Birbir, M. \& Ventosa, A. (2011). Thalassobacillus pellis sp. nov., a moderately halophilic, Grampositive bacterium isolated from salted hides. International Journal of Systematic and Evolutionary Microbiology, 5, 1206-1210. DOI: 10.1099/ijs.0.024778-0

Shirokova, L.S., Mavromatis, V., Bundeleva, I.A., Pokrovsky, O.S., Benezeth, P., Gerard, E., Pearce, C.R. \& Oelkers, E. (2013). Using Mg isotopes to trace cyanobacterially mediated magnesium carbonate precipitation in alkaline lakes. Aquatic Geochemistry, 19, 1-24. DOI: 10.1007/s10498-012-9174-3

Vaishampayan, P., Probst, A., Krishnamurthi, S., Ghosh, S., Osman, S., McDowall, A., Ruckmani, A., Mayilraj, S. \& Venkateswaran, K. (2010). Bacillus horneckiae sp. nov., isolated from a spacecraft-assembly clean room. International Journal of Systematic and Evolutionary Microbiology, 60, 1031-1037. DOI: 10.1099/ijs.0.008979-0

Varol, S., Davraz, A., Şener, Ş., Şener, E., Aksever, F., Kırkan, B. \& Tokgözlü, A. (2021). Assessment of groundwater quality and usability of Salda Lake Basin (Burdur/Turkey) and health risk related to arsenic pollution. Journal of Environmental Health Science and Engineering, 126. DOI: $10.1007 / \mathrm{s} 40201-021-00638-5$

Vijayalakshmi, T.M. \& Murali, R. (2015). Isolation and screening of Bacillus subtilis isolated from the dairy effluent for the production of protease. International Journal of Current Microbiology and Applied Sciences, 4, 12, 820-827.

Wang, C.Y., Hsieh, Y.R., Ng, C.C., Chan, H., Lin, H.T., Tzeng, W.S. \& Shyu, Y.T. (2009). Purification and characterization of a novel halostable cellulase from Salinivibrio sp. strain NTU05. Enzyme and Microbial Technology, 44, 373-379. DOI: 10.1016/j.enzmictec.2009.02.006

WHO (World Health Organization). (2017). Critically important antimicrobials for human medicine, ranking of medically important antimicrobials for risk management of antimicrobial resistance due to non-human use, 5th Revision. Geneva, 1-38. 